\title{
Synthesis, Characterization, and Tautomerism of 1,3-Dimethyl Pyrimidine-2,4,6-Trione s-Triazinyl Hydrazine/Hydrazone Derivatives
}

\author{
Anamika Sharma, ${ }^{1}$ Yahya Jad, ${ }^{1}$ Mohammed R. H. Siddiqui, ${ }^{2}$ Beatriz G. de la Torre, ${ }^{3,4}$ \\ Fernando Albericio, ${ }^{2,4,5,6}$ and Ayman El-Faham ${ }^{2,7}$ \\ ${ }^{1}$ School of Health Sciences, University of KwaZulu-Natal, Durban 4001, South Africa \\ ${ }^{2}$ Department of Chemistry, College of Science, King Saud University, P.O. Box 2455, Riyadh 11451, Saudi Arabia \\ ${ }^{3}$ School of Laboratory Medicine and Medical Sciences, University of KwaZulu-Natal, Durban 4001, South Africa \\ ${ }^{4}$ Department of Organic Chemistry, University of Barcelona, 08028 Barcelona, Spain \\ ${ }^{5}$ CIBER-BBN, Networking Centre on Bioengineering, Biomaterials and Nanomedicine, Barcelona Science Park, \\ 08028 Barcelona, Spain \\ ${ }^{6}$ School of Chemistry and Physics, University of KwaZulu-Natal, Durban 4001, South Africa \\ ${ }^{7}$ Chemistry Department, Faculty of Science, Alexandria University, P.O. Box 426, Ibrahimia, Alexandria 12321, Egypt
}

Correspondence should be addressed to Fernando Albericio; albericio@ukzn.ac.za and Ayman El-Faham; aymanel_faham@hotmail.com

Received 23 January 2017; Revised 31 March 2017; Accepted 12 April 2017; Published 24 May 2017

Academic Editor: José M. G. Martinho

Copyright (C) 2017 Anamika Sharma et al. This is an open access article distributed under the Creative Commons Attribution License, which permits unrestricted use, distribution, and reproduction in any medium, provided the original work is properly cited.

1,3,5-Triazines and pyrimidine-2,4,6-triones belong to that class of compounds which are well known in literature for possessing wide range of biological activities. Here, we report a new family of compounds that encompasses these two structures. The union of both heterocycles was carried out through a hydrazone moiety incorporated into an acetyl group at the position 5 of 1,3dimethyl pyrimidine derivative. The synthetic strategy adopted allowed the preparation of the target compounds with excellent yields and good purities. The synthesized compounds were well characterized by NMR $\left({ }^{1} \mathrm{H}\right.$ and $\left.{ }^{13} \mathrm{C}\right), \mathrm{HRMS}$, and elemental analysis. Furthermore, the tautomerism of enhydrazine versus hydrazone has also been studied.

\section{Introduction}

1,3,5-Triazines and their analogues have gained considerable attention because they are found in numerous natural and synthetic biologically and pharmacologically active targets. 1,3,5-Triazine or s-triazine belongs to the group of heterocyclic compounds having significant applications within pharmaceuticals, textile, rubber, and plastics industries, and as polymer photostabilizers, herbicides, dyestuffs, optical bleaches, explosives, and surface active agents $[1,2]$. Several derivatives of s-triazine have exhibited antimicrobial [3], antibacterial [4], antifungal [3], anti-HIV [5], anticancer [6, 7], and a wide range of other biological activities [8-10]. Recently some of 1,3,5-triazine-Schiff base exhibited some activity against Mycobacterium tuberculosis $\mathrm{H} 37 \mathrm{Rv}$ [11] and moderate to excellent antiproliferative activity with high selectivity against the human lung cancer cell line H460 $[12,13]$. Triazine derivatives are widely employed in many biomedical research fields: cancer chemotherapeutic agents [14], multidrug resistance modulators [15], and trifunctional scaffolds in bundle protein preparation [16].

Pyrimidine-2,4,6-triones (barbiturates) are another group of synthetic compounds known to possess biological activity. Their most remarkable action is on the central nervous system. They are extensively used for producing effects ranging from mild sedation to anaesthesia [17-21] as anticonvulsants, anxiolytics, sedative, and antiepileptic agents, as well as antitumoral agents [22-26]. They have found a prominent 
place in pharmaceutical industry because of their biochemical effects on calcium, acetylcholine, biogenic amines, glutamate, aspartate, and gamma-aminobutyric acid [27]. Other members of this family have found applications as antimicrobial and antifungal agents $[28,29]$. Recently Neumann et al. reported a number of pyrimidine-2,4,6-trione derivatives, including phenylhydrazones of 5-acylpyrimidine-2,4,6-trione exhibiting potent growth inhibition with very low cell toxicity [30].

Prompted by such facts it is worthy to envisage that combination of such bioactive moieties (Figure 1) may form new biologically active agents. Herein, we report the synthesis of novel class of s-triazine-pyrimidinetrione hydrazone derivatives and their tautomeric behavior as well.

\section{Experimental Section}

2.1. Materials. All solvents were used without further purification. The ${ }^{1} \mathrm{H}$ NMR and ${ }^{13} \mathrm{C}$ NMR spectra (Supporting Information Figures S1-S23 in Supplementary Material available online at https://doi.org/10.1155/2017/5702962) were recorded on a JEOL $400 \mathrm{MHz}$ spectrometer at room temperature in $\mathrm{CDCl}_{3}$ and/or DMSO- $\mathrm{d}_{6}$ using internal standard $\delta=$ $0 \mathrm{ppm}$. Elemental analysis were performed on Perkin-Elmer 2400 elemental analyzer. Melting points were determined on a Mel-Temp apparatus and are uncorrected. Fourier transform infrared spectroscopy (FTIR) spectra were recorded on Nicolet 6700 spectrometer from $\mathrm{KBr}$ discs. Ultrasonic bath was purchased from Selecta (Barcelona, Spain). Highresolution mass spectrometric data were obtained using a Bruker microTOF-Q II instrument operating at room temperature and a sample concentration of approximately $1 \mathrm{ppm}$. All compounds were named by using ChemBioDraw Ultra version 14.0, Cambridge Soft Corporation (Cambridge, MA, USA).

2.2. Synthesis of 2-Chloro-4,6-disubstituted-s-triazine Derivatives $\mathbf{2} \boldsymbol{a}-\boldsymbol{h}$. The target chloroderivatives were prepared following the reported method with slight modification [31].

\subsubsection{N-Benzyl-4-chloro-6-(piperidine-1-yl)-1,3,5-} triazine-2-amine (2c, Supporting Information Figure S1 in Supplementary Material)<smiles>Clc1nc(NCc2ccccc2)nc(N2CCCCC2)n1</smiles>

White solid in yield $85 \%$; $\mathrm{mp}=151-152^{\circ} \mathrm{C} ;{ }^{1} \mathrm{H}$ NMR $(400 \mathrm{MHz}$, $\left.\mathrm{CDCl}_{3}\right) \delta=1.54-1.64\left(\mathrm{~m}, 6 \mathrm{H}, 3 \mathrm{CH}_{2}\right), 3.72\left(\right.$ brs, $\left.4 \mathrm{H}, 2 \mathrm{NCH}_{2}\right)$, $4.58\left(\mathrm{t}, 2 \mathrm{H}, \mathrm{J}=4.4 \mathrm{~Hz}, \mathrm{CH}_{2}-\mathrm{Ph}\right) 7.25-7.29\left(\mathrm{~m}, 5 \mathrm{H}, \mathrm{C}_{6} \mathrm{H}_{5}\right) ;{ }^{13} \mathrm{C}$ NMR $\left(100 \mathrm{MHz} \mathrm{CDCl}_{3}\right) \delta=24.6,25.6,25.8,44.6,44.8,127.3$, $127.4,128.5$, 164.0, 165.6, 169.5. Anal. Cacl. for $\mathrm{C}_{15} \mathrm{H}_{18} \mathrm{ClN}_{5}$

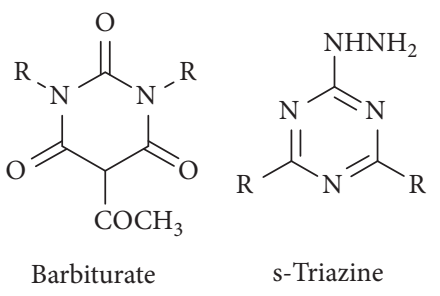

FIGURE 1: General structure of barbiturate and s-triazine.

(303.79): C, 59.30; H, 5.97; N, 23.05; Found: C, 59.15; H, 6.09; N, 23.21.

\subsubsection{N-Benzyl-4-chloro-6-morpholino-1,3,5- triazine-2-amine (2d, Supporting Information Figure S2 in Supplementary Material)}<smiles>Clc1nc(NCc2ccccc2)nc(N2CCOCC2)n1</smiles>

White solid in yield $81 \% ; \mathrm{mp}=158-159^{\circ} \mathrm{C} ;{ }^{1} \mathrm{H} \mathrm{NMR}$ $\left(400 \mathrm{MHz} \mathrm{CDCl}_{3}\right) \delta=3.67$ (brs, $4 \mathrm{H}, 2 \mathrm{NCH}_{2}$ ), 3.77 (brs, $\left.4 \mathrm{H}, 2 \mathrm{OCH}_{2}\right), 4.58\left(\mathrm{~d}, 2 \mathrm{H}, J=6.0 \mathrm{~Hz}, \mathrm{CH}_{2}-\mathrm{Ph}\right), 7.26-7.32(\mathrm{~m}$, $\left.5 \mathrm{H}, \mathrm{C}_{6} \mathrm{H}_{5}\right) ;{ }^{13} \mathrm{C} \mathrm{NMR}\left(100 \mathrm{MHz}, \mathrm{CDCl}_{3}\right) \delta=44.4,44.9,66.2$, 127.4, 128.7, 164.5, 165.6, 169.5. Anal. Cacl. for $\mathrm{C}_{14} \mathrm{H}_{16} \mathrm{ClN}_{5} \mathrm{O}$ (305.77): C, 54.99; H, 5.27; N, 22.90; Found: C, 55.15; H, 5.12; N, 23.13.

\subsubsection{4-(4-Chloro-6-(piperidin-1-yl)-1,3,5-triazine-2- yl)morpholine (2e, Supporting Information Figure S3 in Supplementary Material)}<smiles>Clc1nc(N2CCCCC2)nc(N2CCOCC2)n1</smiles>

White solid in yield $89 \% ; \mathrm{mp}=125-126^{\circ} \mathrm{C} ;{ }^{1} \mathrm{H}$ NMR $\left(400 \mathrm{MHz} \mathrm{CDCl}_{3}\right) \delta=1.52-1.64\left(\mathrm{~m}, 6 \mathrm{H}, 3 \mathrm{CH}_{2}\right), 3.68-3.76$ $\left(\mathrm{m}, 12 \mathrm{H}, 2 \mathrm{OCH}_{2}\right.$, and $\left.4 \mathrm{NCH}_{2}\right) ;{ }^{13} \mathrm{C} \mathrm{NMR}\left(100 \mathrm{MHz}, \mathrm{CDCl}_{3}\right)$ $\delta=24.6,25.8,43.8,44.1,163.9,164.5,169.5$. Anal. Cacl. for $\mathrm{C}_{12} \mathrm{H}_{18} \mathrm{ClN}_{5} \mathrm{O}$ (283.76): C, 50.79; H, 6.39; N, 24.68; Found: C, $50.65 ; \mathrm{H}, 6.41 ; \mathrm{N}, 24.81$. 


\subsubsection{4-Chloro-N,N-diethyl-6-morpholino-1,3,5-} triazine-2-amine (2f, Supporting Information Figure S4 in Supplementary Material)<smiles>CCN(CC)c1nc(Cl)nc(N2CCOCC2)n1</smiles>

White crystals in $87 \%$ yield; $\mathrm{mp}=87-89^{\circ} \mathrm{C} ;{ }^{1} \mathrm{H}$ NMR $\left(400 \mathrm{MHz} \mathrm{CDCl}_{3}\right) \delta=1.11\left(\mathrm{t}, 6 \mathrm{H}, J=7.2 \mathrm{~Hz}, 2 \mathrm{CH}_{3}\right), 3.46-3.53$ $\left(\mathrm{m}, 4 \mathrm{H}, 2 \mathrm{CH}_{2}\right), 3.67$ (brs, $\left.4 \mathrm{H}, 2 \mathrm{NCH}_{2}\right), 3.75$ (brs, $4 \mathrm{H}$, $\left.2 \mathrm{OCH}_{2}\right)$ ppm; ${ }^{13} \mathrm{C} \mathrm{NMR}\left(100 \mathrm{MHz}, \mathrm{CDCl}_{3}\right) \delta=12.5,13.2$, 41.2, 41.6, 41.4, 43.7, 163.9, 164.4, 169.2 ppm. Anal. Cacl. for $\mathrm{C}_{11} \mathrm{H}_{18} \mathrm{ClN}_{5} \mathrm{O}$ (271.75): C, 48.62; H, 6.68; N, 25.77; Found: C, 48.87; H, 6.56; N, 25.99.

\subsubsection{4-Chloro-N,N-diethyl-6-(piperidin-1-yl)-1,3,5-} triazine-2-amine (2g, Supporting Information Figure S5 in Supplementary Material)

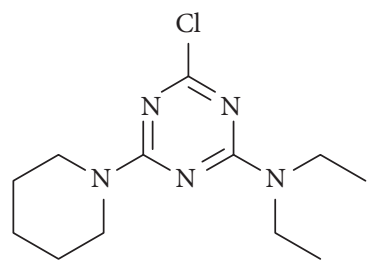

White crystals in $89 \%$ yield; $\mathrm{mp}=54^{\circ} \mathrm{C}$ (Lit [31]; $\mathrm{mp} 56^{\circ} \mathrm{C}$, yield $89 \%) .{ }^{1} \mathrm{H}$ NMR $\left(400 \mathrm{MHz}, \mathrm{CDCl}_{3}\right) \delta=1.09(\mathrm{t}, 6 \mathrm{H}$, $\left.J=7.2 \mathrm{~Hz}, 2 \mathrm{CH}_{3}\right), 1.49-1.59\left(\mathrm{~m}, 6 \mathrm{H}, 3 \mathrm{CH}_{2}\right), 3.43-3.52(\mathrm{q}$, $\left.4 \mathrm{H}, 2 \mathrm{CH}_{2}\right), 3.66\left(\mathrm{t}, 4 \mathrm{H}, \mathrm{J}=5.2 \mathrm{~Hz}, 2 \mathrm{CH}_{2}\right) \mathrm{ppm} ;{ }^{13} \mathrm{CNMR}$ $\left(100 \mathrm{MHz}, \mathrm{CDCl}_{3}\right) \delta=12.5,13.2,24.5,25.6,41.2,41.5,44.3$, 163.9, $169.1 \mathrm{ppm}$.

\subsubsection{4-(4-Chloro-6-methoxy-1,3,5-triazine-2-yl)morpholine} $(\mathbf{2 h}$, Supporting Information Figure S6 in Supplementary Material)<smiles>COc1nc(Cl)nc(N2CCOCC2)n1</smiles>

White crystals in $85 \%$ yield; $\mathrm{mp}=96-97^{\circ} \mathrm{C} ;{ }^{1} \mathrm{H} \mathrm{NMR}$ $\left(400 \mathrm{MHz}, \mathrm{CDCl}_{3}\right) \delta=3.66\left(\mathrm{t}, 4 \mathrm{H}, J=5.2 \mathrm{HMz}, 2 \mathrm{NCH}_{2}\right)$, $3.78\left(\mathrm{t}, 4 \mathrm{H}, \mathrm{J}=4.4,2 \mathrm{OCH}_{2}\right), 3.90\left(\mathrm{~s}, 3 \mathrm{H}, \mathrm{OCH}_{3}\right) \mathrm{ppm} ;{ }^{13} \mathrm{C}$ $\operatorname{NMR}\left(100 \mathrm{MHz}, \mathrm{CDCl}_{3}\right) \delta=43.8,54.4,66.4,166.6,172.1 \mathrm{ppm}$. Anal. Cacl. for $\mathrm{C}_{8} \mathrm{H}_{11} \mathrm{ClN}_{4} \mathrm{O}_{2}$ (230.65): C, 41.66; H, 4.81; N, 24.29; Found: C, 41.82; H, 4.96; N, 24.02.

2.3. General Method for the Synthesis of 2-Hydrazino-4,6disubstituted-1,3,5-triazine $(\mathbf{3} \boldsymbol{a}-\boldsymbol{h})$. The hydrazine derivatives were prepared according to the reported method with slight modification $[12,32]$. Hydrazine hydrate $(10 \mathrm{~mL}, 80 \%)$ was added in portion to a solution of 2-chloro-4,6-disubstituted1,3,5-triazine $\mathbf{2 a}-\mathbf{h}(20 \mathrm{mmol})$ in $50 \mathrm{~mL}$ acetonitrile at room temperature and then the reaction mixture was sonicated for $60 \mathrm{~min}$ at $60^{\circ} \mathrm{C}$. Acetonitrile and excess hydrazine were removed under vacuum and then excess diethylether was added to afford the product as a white solid in yield $>90 \%$ and used directly without further purification for the condensation reaction with 4 .

2.4. Synthesis of 1,3-Dimethyl-5-acetyl Barbituric Acid (4). Compound 4 was prepared following the reported method with slight modification [30, 33]: 1,3-dimethyl barbituric acid $(50 \mathrm{mmol})$ was suspended in very small amount of water (5-10 $\mathrm{mL})$ and a concentrated water solution of sodium bicarbonate $\left(\mathrm{NaHCO}_{3}, 50 \mathrm{mmol}\right)$ was added. Acetic anhydride was added after the gas evolution ceased. The white precipitate was formed after about 5 minutes and the mixture was stirred overnight at room temperature. The white precipitate was filtered and dissolved in 15-20\% ammonium hydroxide $\left(\mathrm{NH}_{4} \mathrm{OH}\right)$. To neutralise, hydrochloric acid $(\mathrm{HCl})$ was added under cold conditions (as the reaction is exothermic) until $\mathrm{pH}$ was below 1 . The increase in temperature was witnessed followed by formation of precipitate which was filtered and allowed to dry at room temperature. The product obtained as white solid from ethanol in yield $83 \%$; mp $94-96{ }^{\circ} \mathrm{C} ;{ }^{1} \mathrm{H}$ $\operatorname{NMR}\left(400 \mathrm{MHz} \mathrm{CDCl}_{3}\right) \delta=2.70\left(\mathrm{~s}, 3 \mathrm{H}, \mathrm{CH}_{3}\right), 3.32(\mathrm{~s}, 3 \mathrm{H}$, $\mathrm{CH}_{3}$ ), 3.35 (s, 3H, $\mathrm{CH}_{3}$ ), 17.21 (s, $1 \mathrm{H}$, enolic $\left.\mathrm{OH}\right) ;{ }^{13} \mathrm{C} \mathrm{NMR}$ $\left(100 \mathrm{MHz} \mathrm{CDCl}_{3}\right) \delta=24.8,27.9,28.1,95.9,150.5,161.2,169.5$, 196.2 (Supporting Information Figure S7 in Supplementary Material).

2.5. General Method for the Synthesis of Pyrimidine-2,4,6trione s-1,3,5-Triazine Hydrazine Derivatives (5a-h). To a solution of $4(10 \mathrm{mmol})$ in ethanol $(30 \mathrm{~mL})$ containing 23 drops of acetic acid, 2-hydrazino-4,6-disubstituted-1,3,5triazine $\mathbf{3} \mathbf{a}-\mathbf{h}(10 \mathrm{mmol})$ was added and the reaction mixture was stirred under reflux for $3 \mathrm{~h}$. The solvent was reduced under vacuum and the precipitated product was filtered off and dried at room temperature. The products were collected and recrystallized from ethylacetate. 
2.5.1. 5-(1-(2-(4,6-Dimorpholino-1,3,5-triazin-2yl)hydrazinyl)ethylidene)-1,3-dimethyl Pyrimidine-2,4,6(1H,3H,5H)-trione (5a, Supporting Information Figure S8 in Supplementary Material)<smiles>CC(NNc1nc(N2CCOCC2)nc(N2CCOCC2)n1)=C1C(=O)N(C)C(=O)N(C)C1=O</smiles>

White solid, $82 \%$ yield, $\mathrm{mp}=142-144^{\circ} \mathrm{C}$, IR $\left(\mathrm{KBr}, \mathrm{cm}^{-1}\right)$ $3244(\mathrm{NH}), 1695,1651(\mathrm{C}=\mathrm{O}), 1593(\mathrm{C}=\mathrm{N}, \mathrm{C}=\mathrm{C}) ;{ }^{1} \mathrm{H}$ NMR $\left(400 \mathrm{MHz}, \mathrm{CDCl}_{3}\right) \delta=2.75\left(\mathrm{~s}, 3 \mathrm{H}, \mathrm{CH}_{3}\right), 3.30(\mathrm{~s}, 6 \mathrm{H}$, $\left.2 \mathrm{CH}_{3}\right), 3.69-3.74\left(\mathrm{~m}, 16 \mathrm{H}, 8 \mathrm{CH}_{2}\right), 14.21(\mathrm{~s}, 1 \mathrm{H}, \mathrm{NH}),{ }^{13} \mathrm{C}$ NMR $\left(100 \mathrm{MHz}, \mathrm{CDCl}_{3}\right) \delta=16.8,27.7,27.9,43.8,61.6$, 89.4, 151.3, 162.7, 163.7, 165.9, 171.3. HRMS (ESI+, Supporting Information Figure S9 in Supplementary Material) m/z calcd for $\mathrm{C}_{19} \mathrm{H}_{27} \mathrm{~N}_{9} \mathrm{O}_{5}[\mathrm{M}+\mathrm{H}]^{+}=462.2208$; found: 462.2215; Anal. Calc. for $\mathrm{C}_{19} \mathrm{H}_{27} \mathrm{~N}_{9} \mathrm{O}_{5}$ (461.48): C, 49.45; H, 5.90; N, 27.32; Found: C, 49.66; H, 5.98; N, 27.45.

\subsection{2. (Z)-5-(1-(2-(4,6-Di(piperidin-1-yl)-1,3,5-triazin-}

2-yl)hydrazono)ethyl)-1,3-dimethylpyrimidine2,4,6(1H,3H,5H)-trione (5b, Supporting Information Figure S10 in Supplementary Material)<smiles>CC(NNc1nc(N2CCCCC2)nc(N2CCCCC2)n1)=C1C(=O)N(C)C(=O)N(C)C1=O</smiles>

White solid, $87 \%$ yield, $\mathrm{mp}=224-226^{\circ} \mathrm{C}, \mathrm{IR}\left(\mathrm{KBr}, \mathrm{cm}^{-1}\right)$ $3213(\mathrm{NH}), 1701,1651$ (C=O), $1593(\mathrm{C}=\mathrm{N}, \mathrm{C}=\mathrm{C}) ;{ }^{1} \mathrm{H}$ NMR $\left(400 \mathrm{MHz}, \mathrm{CDCl}_{3}\right) \delta=1.54-1.63\left(\mathrm{~m}, 12 \mathrm{H}, 6 \mathrm{CH}_{2}\right), 2.74(\mathrm{~s}, 3 \mathrm{H}$, $\left.\mathrm{CH}_{3}\right), 3.30\left(\mathrm{~s}, 6 \mathrm{H}, 2 \mathrm{CH}_{3}\right), 3.68-3.71\left(\mathrm{~m}, 8 \mathrm{H}, 4 \mathrm{CH}_{2}\right), 14.35(\mathrm{~s}$, $1 \mathrm{H}, \mathrm{NH}),{ }^{13} \mathrm{C} \mathrm{NMR}\left(100 \mathrm{MHz}, \mathrm{CDCl}_{3}\right) \delta=16.8,24.7,25.7,27.7$, 44.4, 89.0, 151.5, 163.0, 163.4, 169.7, HRMS (ESI+, Supporting Information Figure S11 in Supplementary Material) m/z calcd for $\mathrm{C}_{21} \mathrm{H}_{31} \mathrm{~N}_{9} \mathrm{O}_{3}[\mathrm{M}+\mathrm{H}]^{+}=458.2623$; found: 458.2651. Anal. Calc. for $\mathrm{C}_{21} \mathrm{H}_{31} \mathrm{~N}_{9} \mathrm{O}_{3}$ (457.54): C, 55.13; $\mathrm{H}, 6.83$; N, 27.55; Found: C, 55.29; H, 6.90; N, 27.74.

2.5.3. (Z)-5-(1-(2-(4-(Benzylamino)-6-(piperidin-1-yl)-1,3,5triazin-2-yl)hydrazono)ethyl)-1,3-dimethylpyrimidine2,4,6(1H,3H,5H)-trione (5c, Supporting Information Figure S12 in Supplementary Material)<smiles>CC(NNc1nc(NCc2ccccc2)nc(N2CCCCC2)n1)=C1C(=O)N(C)C(=O)N(C)C1=O</smiles>

White solid, $83 \%$ yield, $\mathrm{mp}=193-194^{\circ} \mathrm{C}$, IR $\left(\mathrm{KBr}, \mathrm{cm}^{-1}\right) 3336$, $3250(\mathrm{NH}), 1678,1622(\mathrm{C}=\mathrm{O}), 1577(\mathrm{C}=\mathrm{N}, \mathrm{C}=\mathrm{C}) ;{ }^{1} \mathrm{H}$ NMR $\left(400 \mathrm{MHz} \mathrm{CDCl}_{3}\right) \delta=1.54-1.64\left(\mathrm{~m}, 6 \mathrm{H}, 3 \mathrm{CH}_{2}\right), 2.69(\mathrm{~s}, 3 \mathrm{H}$, $\left.\mathrm{CH}_{3}\right), 3.28\left(\mathrm{~s}, 6 \mathrm{H}, 2 \mathrm{CH}_{3}\right), 3.72\left(\mathrm{~s}, 4 \mathrm{H}, 2 \mathrm{CH}_{2}\right), 4.52(\mathrm{~d}, 2 \mathrm{H}, \mathrm{J}=$ $6 \mathrm{~Hz}, \mathrm{CH}_{2}$ ), 5.90 (s, $\left.1 \mathrm{H}, \mathrm{NH}\right), 7.23-7.27$ (m, 5H, CH aromatic), $14.8(\mathrm{~s}, 1 \mathrm{H}, \mathrm{NH}),{ }^{13} \mathrm{C} \mathrm{NMR}\left(100 \mathrm{MHz}, \mathrm{CDCl}_{3}\right) \delta=12.3$, 17.1, 18.4, 24.6, 25.7, 43.1, 44.8, 58.4, 91.2, 167.4, 177.3, HRMS (ESI+, Supporting Information Figure S13 in Supplementary Material) $\mathrm{m} / \mathrm{z}$ calcd for $\mathrm{C}_{23} \mathrm{H}_{29} \mathrm{~N}_{9} \mathrm{O}_{3}[\mathrm{M}+\mathrm{H}]^{+}=480.2466$; found: 480.2468. Anal. Calc. for $\mathrm{C}_{23} \mathrm{H}_{29} \mathrm{~N}_{9} \mathrm{O}_{3}$ (479.55): C, 57.61; H, 6.10; N, 26.29; Found: C, 57.87; H, 6.22; N, 26.53.

\subsection{4. (Z)-5-(1-(2-(4-(Benzylamino)-6-morpholino-1,3,5-} triazin-2-yl)hydrazono)ethyl)-1,3-dimethylpyrimidine2,4,6(1H,3H,5H)-trione (5d, Supporting Information Figure S14 in Supplementary Material)<smiles>CC(NNc1nc(NCc2ccccc2)nc(N2CCOCC2)n1)=C1C(=O)N(C)C(=O)N(C)C1=O</smiles>

White solid, $83 \%$ yield, $\mathrm{mp}=233-235^{\circ} \mathrm{C}, \mathrm{IR}\left(\mathrm{KBr}, \mathrm{cm}^{-1}\right) 3336$, $3292(\mathrm{NH}), 1681,1612(\mathrm{C}=\mathrm{O}), 1583(\mathrm{C}=\mathrm{N}, \mathrm{C}=\mathrm{C}) ;{ }^{1} \mathrm{H}$ NMR $\left(400 \mathrm{MHz}, \mathrm{DMSO}-\mathrm{d}_{6}\right) \delta=2.66\left(\mathrm{~s}, 3 \mathrm{H}, \mathrm{CH}_{3}\right), 3.13(\mathrm{~s}, 6 \mathrm{H}$, $\left.2 \mathrm{CH}_{3}\right), 3.59-3.68\left(\mathrm{~m}, 8 \mathrm{H}, 4 \mathrm{CH}_{2}\right), 4.46\left(\mathrm{~s}, 2 \mathrm{H}, \mathrm{CH}_{2}\right), 7.22-7.20$ (m, 6H, 5 Ar-H, NH), 14.2 (s, 1H, NH) ${ }^{13} \mathrm{C}$ NMR $(100 \mathrm{MHz}$, DMSO- $\left.\mathrm{d}_{6}\right) \delta=16.4,27.3,43.5,65.9,91.3,126.8,127.4,128.2$, 
150.8, 167.4, 177.3 (s, 1H, CH) HRMS (ESI+, Supporting Information Figure S15 in Supplementary Material) $\mathrm{m} / \mathrm{z}$ calcd for $\mathrm{C}_{22} \mathrm{H}_{27} \mathrm{~N}_{9} \mathrm{O}_{4}[\mathrm{M}+\mathrm{H}]^{+}=482.2259$; found: 482.2242. Anal. Calc. for $\mathrm{C}_{22} \mathrm{H}_{27} \mathrm{~N}_{9} \mathrm{O}_{4}$ (481.52): C, 54.88; H, 5.65; N, 26.18; Found: C, 54.63; H, 5.54; N, 26.00.

\subsection{5. (Z)-1,3-Dimethyl-5-(1-(2-(4-morpholino-6-(piperidin-} 1-yl)-1,3,5-triazin-2-yl)hydrazono)ethyl) pyrimidine2,4,6(1H,3H,5H)-trione (5e, Supporting Information Figure S16 in Supplementary Material)<smiles>CC(NNc1nc(N2CCCCC2)nc(N2CCOCC2)n1)=C1C(=O)N(C)C(=O)N(C)C1=O</smiles>

Yellow solid, $80 \%$ yield, $\mathrm{mp}=198-199^{\circ} \mathrm{C}$, IR $\left(\mathrm{KBr}, \mathrm{cm}^{-1}\right)$ $3246(\mathrm{NH}), 1688,1651(\mathrm{C}=\mathrm{O}), 1585(\mathrm{C}=\mathrm{N}, \mathrm{C}=\mathrm{C}) ;{ }^{1} \mathrm{H}$ NMR $\left(400 \mathrm{MHz}, \mathrm{CDCl}_{3}\right) \delta=1.57-1.66\left(\mathrm{~m}, 6 \mathrm{H}, 3 \mathrm{CH}_{2}\right), 2.77(\mathrm{~s}, 3 \mathrm{H}$, $\left.\mathrm{CH}_{3}\right), 3.30\left(\mathrm{~s}, 6 \mathrm{H}, 2 \mathrm{CH}_{3}\right), 3.69-3.79\left(\mathrm{~m}, 12 \mathrm{H}, 6 \mathrm{CH}_{2}\right), 14.35$ $(\mathrm{s}, 1 \mathrm{H}, \mathrm{NH}),{ }^{13} \mathrm{C} \mathrm{NMR}\left(100 \mathrm{MHz}, \mathrm{CDCl}_{3}\right) \delta=16.8,18.4,24.5$, 25.8, 43.7, 44.0, 44.9, 58.4, 66.6, 89.4, 151.4, 162.4, 170.7, HRMS (ESI+, Supporting Information Figure S17 in Supplementary Material) $\mathrm{m} / \mathrm{z}$ calcd for $\mathrm{C}_{20} \mathrm{H}_{29} \mathrm{~N}_{9} \mathrm{O}_{4}[\mathrm{M}+\mathrm{H}]^{+}=460.2415$; found: 460.2398. Anal. Calc. for $\mathrm{C}_{20} \mathrm{H}_{29} \mathrm{~N}_{9} \mathrm{O}_{4}$ (459.51): C, 52.28; H, 6.36; N, 27.43; Found: C, 52.51; H, 6.54; N, 27.70.

\subsection{6. (Z)-5-(1-(2-(4-(Diethylamino)-6-morpholino-1,3,5-} triazin-2-yl)hydrazono)ethyl)-1,3-dimethylpyrimidine2,4,6(1H,3H,5H)-trione (5f, Supporting Information Figure S18 in Supplementary Material)<smiles>CCN(CC)c1nc(NNC(C)=C2C(=O)N(C)C(=O)N(C)C2=O)nc(N2CCOCC2)n1</smiles>

Orange solid, $91 \%$ yield, $\mathrm{mp}=165-167^{\circ} \mathrm{C}$, IR $\left(\mathrm{KBr}, \mathrm{cm}^{-1}\right)$ $3285(\mathrm{NH}), 1677,1645(\mathrm{C}=\mathrm{O}), 1595(\mathrm{C}=\mathrm{N}, \mathrm{C}=\mathrm{C}) ;{ }^{1} \mathrm{H}$ NMR $\left(400 \mathrm{MHz}^{\mathrm{CDCl}}{ }_{3}\right) \delta=1.11\left(\mathrm{t}, 6 \mathrm{H}, J=6.4 \mathrm{~Hz}, 2 \mathrm{CH}_{3}\right), 2.75(\mathrm{~s}$,
$3 \mathrm{H}, \mathrm{CH}_{3}$ ), 3.27-3.29 (m, 6H, 2CH $\mathrm{CH}_{3}, 3.51(\mathrm{q}, 4 \mathrm{H}, J=6.4 \mathrm{~Hz}$, $\left.2 \mathrm{CH}_{2}\right), 3.66-3.75\left(\mathrm{~m}, 8 \mathrm{H}, 4 \mathrm{CH}_{2}\right), 14.25(\mathrm{~s}, 1 \mathrm{H}, \mathrm{CH}),{ }^{13} \mathrm{C} \mathrm{NMR}$ $\left(100 \mathrm{MHz}, \mathrm{CDCl}_{3}\right) \delta=13.2,16.0,16.8,27.7,27.9$, 41.0, 41.6, 43.6, 43.8, 66.7, 66.9, 89.2, 151.4, HRMS (ESI+, Supporting Information Figure S19 in Supplementary Material) $\mathrm{m} / \mathrm{z}$ calcd for $\mathrm{C}_{19} \mathrm{H}_{29} \mathrm{~N}_{9} \mathrm{O}_{4}[\mathrm{M}+\mathrm{H}]^{+}=448.2415$; found: 448.2400. Anal. Calc. for $\mathrm{C}_{19} \mathrm{H}_{29} \mathrm{~N}_{9} \mathrm{O}_{4}$ (447.50): C, 51.00; H, 6.53; N, 28.17; Found: C, 51.24; H, 6.69; N, 28.41.

\subsection{7. (Z)-5-(1-(2-(4-(Diethylamino)-6-(piperidin-1-yl)-1,3,5-} triazin-2-yl)hydrazono)ethyl)-1,3-dimethylpyrimidine2,4,6(1H,3H,5H)-trione (5g, Supporting Information Figure S20 in Supplementary Material)<smiles>CCN(CC)c1nc(NNC(C)=C2C(=O)N(C)C(=O)N(C)C2=O)nc(N2CCCCC2)n1</smiles>

White solid, $90 \%$ yield, $\mathrm{mp}=135-137^{\circ} \mathrm{C}$, IR $\left(\mathrm{KBr}, \mathrm{cm}^{-1}\right)$ $3285(\mathrm{NH}), 1677,1645(\mathrm{C}=\mathrm{O}), 1595(\mathrm{C}=\mathrm{N}, \mathrm{C}=\mathrm{C}) ;{ }^{1} \mathrm{H}$ NMR $\left(400 \mathrm{MHz} \mathrm{CDCl}_{3}\right) \delta=1.11\left(\mathrm{t}, 6 \mathrm{H}, J=6.8 \mathrm{~Hz}, 2 \mathrm{CH}_{3}\right), 1.54-1.62$ $\left(\mathrm{m}, 6 \mathrm{H}, 3 \mathrm{CH}_{2}\right), 2.75\left(\mathrm{~s}, 3 \mathrm{H}, \mathrm{CH}_{3}\right), 3.30\left(\mathrm{~m}, 6 \mathrm{H}, 2 \mathrm{CH}_{3}\right), 3.51$ $\left(\mathrm{q}, 4 \mathrm{H}, J=6.8 \mathrm{~Hz}, 2 \mathrm{CH}_{2}\right), 3.68-3.71\left(\mathrm{~m}, 4 \mathrm{H}, 2 \mathrm{CH}_{2}\right), 14.35$ $(\mathrm{s}, 1 \mathrm{H}, \mathrm{CH}),{ }^{13} \mathrm{C} \mathrm{NMR}\left(100 \mathrm{MHz}, \mathrm{CDCl}_{3}\right) \delta=13.1,16.8$, 24.7, 25.7, 27.7, 41.6, 44.5, 89.0, 151.5, 162.5, 162.7, 169.7, HRMS (ESI+, Supporting Information Figure S21 in Supplementary Material) $\mathrm{m} / \mathrm{z}$ calcd for $\mathrm{C}_{20} \mathrm{H}_{31} \mathrm{~N}_{9} \mathrm{O}_{3}[\mathrm{M}+\mathrm{H}]^{+}=446.2623$; found: 446.2609. Anal. Calc. for $\mathrm{C}_{20} \mathrm{H}_{31} \mathrm{~N}_{9} \mathrm{O}_{3}$ (445.53): C, 53.92; H, 7.01; N, 28.30; Found: C, 54.09; H, 7.20; N, 28.54.

\subsection{8. (Z)-5-(1-(2-(4-Methoxy-6-morpholino-1,3,5-triazin- 2-yl)hydrazono)ethyl)-1,3-dimethylpyrimidine- 2,4,6(1H,3H,5H)-trione (5h, Supporting Information Figure S22 in Supplementary Material)}<smiles>COc1nc(NNC(C)=C2C(=O)N(C)C(=O)N(C)C2=O)nc(N2CCOCC2)n1</smiles> 


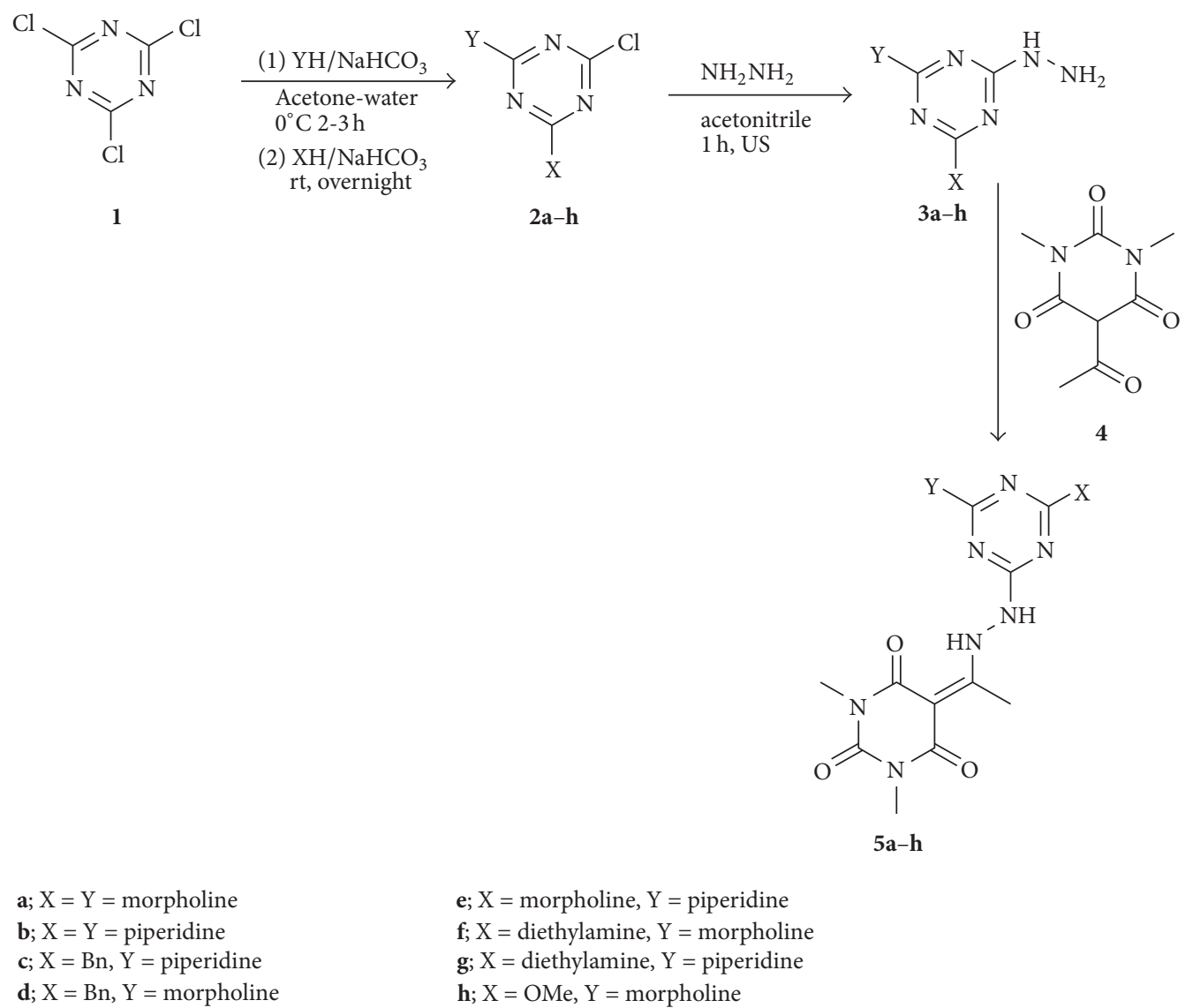

SCHEme 1: Synthesis of pyrimidinetrione-s-triazine derivatives.

White solid, $87 \%$ yield, $\mathrm{mp}=260-262^{\circ} \mathrm{C}$, IR $\left(\mathrm{KBr}, \mathrm{cm}^{-1}\right)$ $3321(\mathrm{NH}), 1686,1651(\mathrm{C}=\mathrm{O}), 1588(\mathrm{C}=\mathrm{N}, \mathrm{C}=\mathrm{C}) ;{ }^{1} \mathrm{H}$ NMR $\left(400 \mathrm{MHz}, \mathrm{CDCl}_{3}\right) \delta=2.76\left(\mathrm{~s}, 3 \mathrm{H}, \mathrm{CH}_{3}\right), 3.30\left(\mathrm{~s}, 6 \mathrm{H}, 2 \mathrm{CH}_{3}\right)$, 3.78-3.97 (m, 8H, 4CH $), 4.07$ (s, 3H, $\left.\mathrm{CH}_{3}\right), 14.65$ (s, $\left.1 \mathrm{H}, \mathrm{NH}\right)$, ${ }^{13} \mathrm{C} \mathrm{NMR}\left(100 \mathrm{MHz}, \mathrm{CDCl}_{3}\right) \delta=16.9,45.1,45.3,56.4,66.3$, 66.4 , 90.0, 151.2, 156.6, 161.0, 161.4, 162.0, 162.5, 170.9, HRMS (ESI+, Supporting Information Figure S23 in Supplementary Material) $\mathrm{m} / \mathrm{z}$ calcd for $\mathrm{C}_{16} \mathrm{H}_{22} \mathrm{~N}_{8} \mathrm{O}_{5}[\mathrm{M}+\mathrm{H}]^{+}=407.1786$; found: 407.1771. Anal. Calc. for $\mathrm{C}_{16} \mathrm{H}_{22} \mathrm{~N}_{8} \mathrm{O}_{5}$ (406.40): C, 47.29; H, 5.46; N, 27.57; Found: C, 47.54; H, 5.53; N, 27.82.

\section{Results and Discussion}

The general method for the preparation of triazine derivatives is nucleophilic displacement of chlorine present in the inexpensive commercially available cyanuric chloride $(1,2,4,6-$ trichloro-1,3,5-triazine) because of the reactivity of its chlorine atoms toward nucleophiles in presence of hydrochloride acceptor like sodium carbonate, bicarbonate, hydroxide, or tertiary amines [34-36]. Here, we report synthesis of 2chloro-4,6-disubstituted-s-triazine derivatives using 1 . Secondary amines like morpholine, diethylamine, and piperidine were chosen due to their known pharmacological properties $[1,37]$. Taking advantage of the different reactivity in front of the nucleophiles of the tri-, di-, and monochloroderivatives of s-triazine, products $\mathbf{2 a - \mathbf { i }}$ (Scheme 1) were obtained through one pot reaction [12]. Thus, 1 was reacted at $0^{\circ} \mathrm{C}$ for $2 \mathrm{~h}$ with the first amine (1 equiv.) in acetone-water media or methanol in the presence of $\mathrm{NaHCO}_{3}$ (1 equiv.) as hydrogen chloride scavengers. The second amine was added dropwise followed by addition of $\mathrm{NaHCO}_{3}$ (1 equiv.) and the reaction temperature was raised gradually to room temperature and kept under stirring for $12 \mathrm{~h}$ (Scheme 1) to afford the target product. In case of the methoxy derivative $\mathbf{2 h}$, the reported method [33] was used for its preparation and then reacted with the amine as mentioned in Scheme 1. Finally, the hydrazine derivatives $\mathbf{3} \mathbf{a}-\mathbf{h}$ were obtained by treatment of $\mathbf{2} \mathbf{a}-\mathbf{h}$ with hydrazine hydrate $(80 \%)$ in acetonitrile and sonicated for $1 \mathrm{~h}$ [12] to afford the products in excellent yields and purities above $90 \%$. (Scheme 1) which was used directly with 5-acetyl-1,3-dimethylbarbituric acid 4 without further purification.

The products $\mathbf{5} \mathbf{a}-\mathbf{h}$ were obtained by reaction of the 2 hydrazino-4,6-disubstituted-s-triazine derivatives $\mathbf{3 a - h}$ with 1,3 dimethyl-5-acetylpyrimidine-2,4,6-trione 4, which was obtained as previously described [33] in ethanol in the presence of drops of glacial acetic acid (Scheme 1) to afford the target products in excellent yields and purities as observed from their spectral data.

Compound 4 may exist in three tautomeric forms $4 \mathrm{~A}, \mathbf{4 B}$, and $4 \mathrm{C}$ as shown in Figure 2. In solution, the NMR spectra in $\mathrm{CDCl}_{3}$ showed that it exists in the enol form $4 \mathrm{C}$ which 


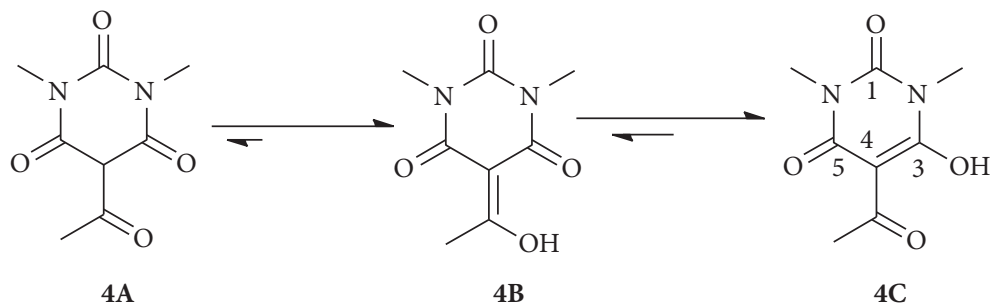

FIGURE 2: Enol-keto form for the acylpyrimidine derivatives.

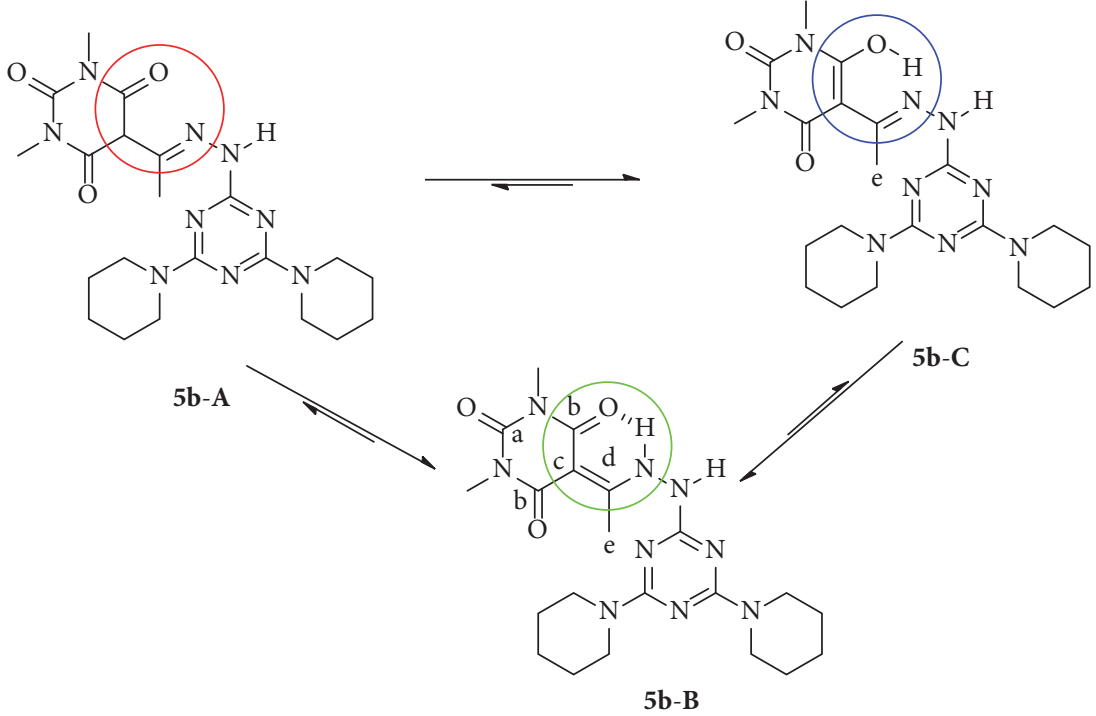

FIgURE 3: Tautomeric structure of $\mathbf{5 b}$.

agreed with our previous reported data [35], rather than keto form 4A (Figure 2). The ${ }^{1} \mathrm{H}$ NMR spectra for compound 4 showed a singlet at $\delta$ 17.24; this peak is related to the $\mathrm{OH}$ group of the enol form $4 \mathrm{C}$ and it appears at low field due to the strong hydrogen bond between the $\mathrm{OH}$ and the carbonyl carbon of the acetyl group. On the other hand, the expected peak at $\delta 4.3$ related to the $\mathrm{CH}$ flanked between the two carbonyl groups (-CO-CH-CO-) in the keto form $\mathbf{4 A}$ was not observed. The ${ }^{1} \mathrm{H}$ NMR showed that two singlet peaks at $\delta$ 3.29 and 3.34 related to the two $\mathrm{N}-\mathrm{CH}_{3}$ which agreed with structure $4 \mathrm{C}$ rather than $\mathbf{4 B}$. The ${ }^{13} \mathrm{C}$ NMR for compound 4 also confirmed the enol form $4 \mathrm{C}$ rather than the keto form or the enol form $4 \mathbf{B}$, where ${ }^{13} \mathrm{C}$ NMR showed peaks at $\delta$ $24.8\left(\mathrm{CH}_{3}\right)$, two peaks at 27.9 and 28.1 for the $2 \mathrm{~N}-\mathrm{CH}_{3}$, 95.9 (C4=C-OH), $150.5(\mathrm{Cl}), 161.0$ (C5), 169.5 (acetyl C=O), and $196.2(\mathrm{C}=\mathbf{C} 3-\mathrm{OH})$ (Supporting Information Figure S7 in Supplementary Material). This observation is in agreement with the reported data by Sharma et al. [38] and Giziroglu et al. [39].

Once it is established that $\mathbf{4}$ exists only in an enol form, the structure of $\mathbf{5 a}-\mathbf{h}$ was studied, in particular respect to the enhydrazine-hydrazone tautomerism. In this case, the hydrazine moiety incorporates two $\mathrm{NH}$. Thus in addition to the NH (in green, Figure 3), which can stabilizes the molecule (enhydrazine form) through a six-member ring as happens in the case of the enol form $\mathbf{4 B}$ or $\mathbf{4 C}$ (Figure 2), which is not the case for the hydrazone form $\mathbf{5 b}$-A. The NMR data supported the structure $\mathbf{5 b}-\mathbf{B}$ more than the others.

Taking as example compound $\mathbf{5 b}$, it may exist in three tautomeric structures $\mathbf{5 b}-\mathbf{A}, \mathbf{5 b}-\mathbf{B}$, and $\mathbf{5 b}-\mathbf{C}$ as indicated in Figure $3 .{ }^{1} \mathrm{H}$ NMR in DMSO- $\mathrm{d}_{6}$ showed multiple peaks at $\delta 1.54-1.63$ for the three methylene groups $\left(-\mathrm{CH}_{2}-\right)_{3}$ of the piperidine moiety, singlet at $\delta 2.74$ for the methyl group $\left(\mathrm{N}=\mathrm{C}-\mathrm{CH}_{3}\right)$, singlet at $\delta 3.29$ for the two methyl group ( $\mathrm{N}$ $\left.\mathrm{CH}_{3}\right)$, triplet for the two methylene groups $\left(-\mathrm{CH}_{2} \mathrm{~N}\right)_{2}$ of piperidine ring, and a singlet peak at $\delta 14.4$ for $\mathrm{NH}$ related to the hydrazine moiety. The ${ }^{13} \mathrm{C}$ NMR of $\mathbf{5 b}$ showed peaks at $\delta 17.1\left(\mathrm{C}_{\mathrm{e}}\right), 24.86,25.8\left(\mathrm{CH}_{2}\right.$, piperidine $), 27.4\left(2 \mathrm{~N}-\mathrm{CH}_{3}\right)$, $44.4\left(2 \mathrm{~N}-\mathrm{CH}_{2}\right.$, piperidine), $89.2\left(\boldsymbol{C}_{\mathrm{c}}\right), 151.5,163.1,163.6$, and $169.8\left(C_{\mathrm{a}}, \boldsymbol{C}_{\mathrm{b}}, C_{\mathrm{d}}\right.$, and $\boldsymbol{C}=\mathrm{N}$ of triazine $)$. These data are in good agreement with the structure $\mathbf{5 b}-\mathbf{B}$ more than $\mathbf{5 b}-\mathbf{C}$. The HRMS showed the exact mass 480.2451 as calculated for $\mathrm{C}_{23} \mathrm{H}_{35} \mathrm{~N}_{9} \mathrm{O}_{2} \mathrm{~S}[\mathrm{M}+\mathrm{H}]^{+}=480.2466$ (Supporting Information Figure S11 in Supplementary Material).

The NMR data for all the target products showed that $\mathbf{5 a}-\mathbf{h}$ exist in the enhydrazine form $\mathbf{B}$ rather than the hydrazone form $\mathbf{A}$ or $\mathbf{C}$ as shown in Figure 3, where the two peaks in range of $\delta 90.0$ and $198.0 \mathrm{ppm}$ are related to the two carbon similar to those of the enhydrazine form $(\mathrm{C}=\mathrm{C}-\mathrm{NH}-\mathrm{NH}-)$. In addition, the hydrogen bond in the enhydrazine form stabilizes the structure $\mathbf{5 b}$ - $\mathbf{B}$ more than the hydrazone isomer $\mathbf{5 b}-\mathbf{A}$ as shown in Figure 3. This is also in agreement with 


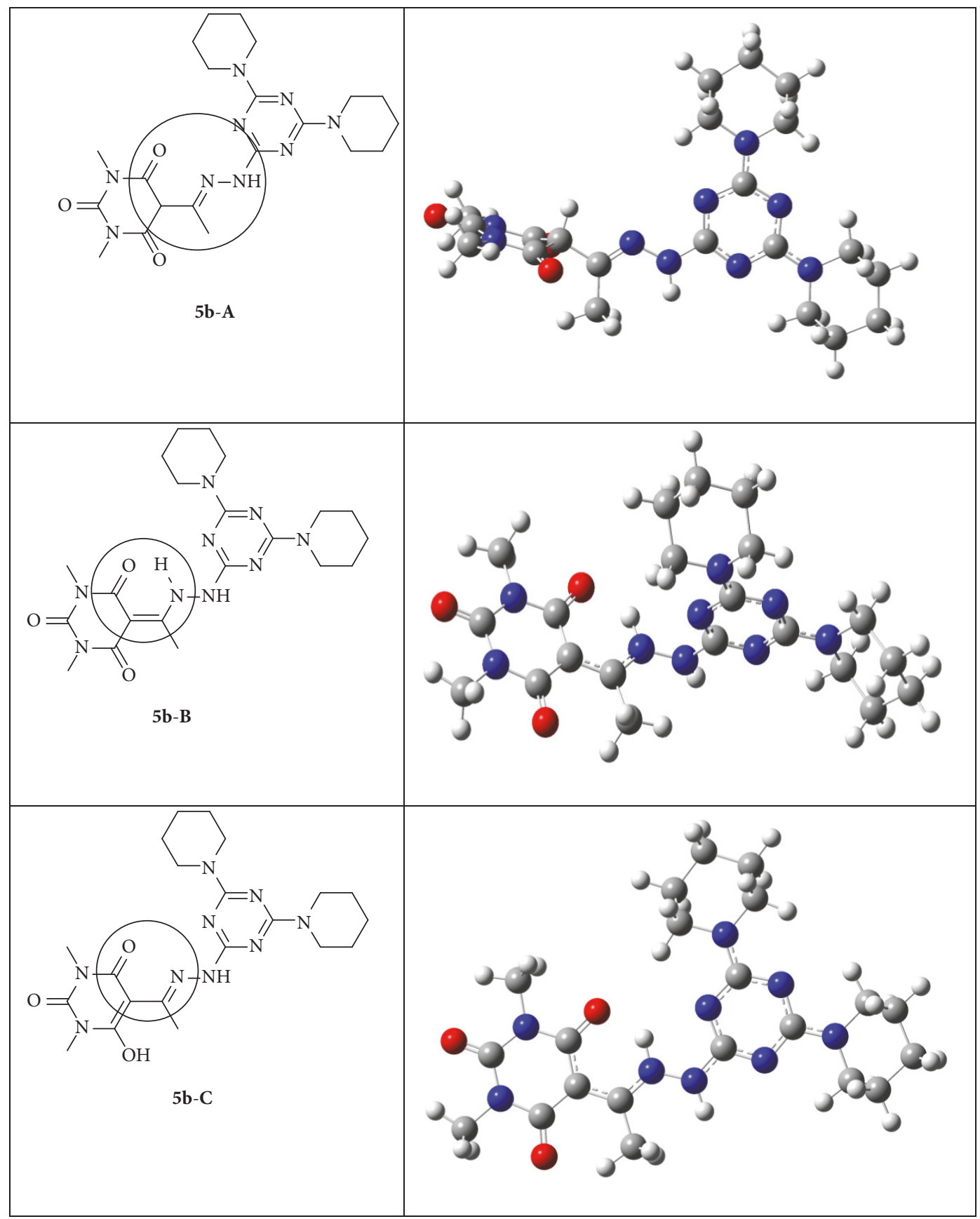

FIGURE 4: The expected 3D tautomeric structure of compound $\mathbf{5 b}$.

the reported data for aroylhydrazine derivatives reported by Giziroglu et al. [39].

To expand the scope of this work, compound $\mathbf{5 b}$ was modelled using molecular mechanics MM2 calculations. Quantum mechanical calculations were carried out using Gaussian98 suite of programs. Geometry optimization was done by DFT method using B3LYP/6-31G** basis set to assess the relative stability of the diastereomeric species (Figure 4). The calculated relative energy of hydrazone $(\mathbf{5 b}-\mathbf{A})$ is $-963917.8 \mathrm{kcal} / \mathrm{mole}$ while that of enhydrazine $(5 \mathbf{b}-\mathbf{B})$ is $-963940.7 \mathrm{kcal} / \mathrm{mole}$, while the calculated relative energy of $\mathbf{5 b}-\mathbf{C}$ geometry was optimized and found to be $-963939.1561 \mathrm{kcal} / \mathrm{mol}$, which shows higher energy level when compared with $\mathbf{5 b}-\mathbf{A}$ and $\mathbf{5 b}-\mathbf{B}$. Hence on comparison $\mathbf{5 b}-\mathbf{C}$ is found to be least stable amongst all the three diastereomers. From the energy values it can be seen that theoretically $\mathbf{5 b}-\mathbf{B}$ is more favorable compared to $\mathbf{5 b}-\mathbf{A}$ and $\mathbf{5 b} \mathbf{b}-\mathbf{C}$. From the energy values it can be found that the difference in energy level is $22.9 \mathrm{kcal} / \mathrm{mol}$. Hence, explaining the stability of the enhydrazine (5b-B) form over hydrazone form (5b-A).

The antibacterial screening for all the products against gram positive [S. aureus (29213) and B. subtilis (6051) and 
gram negative E. coli (25822) and P. aeruginosa (27583)] showed no activity; this might be due to the poor solubility and precipitation during the dilution process.

\section{Conclusion}

Reaction of 2-hydrazino-2,6-disubstituted-1,3,5-triazine with 5-acetyl-1,3-dimethyl barbituric acid in ethanol affords the hydrazine derivatives in the enhydrazine form as a pure isomer rather than the hydrazone form as observed from the spectral data. The geometry optimization was done by DFT method using B3LYP/6-31G ${ }^{* *}$ to calculate the relative energy of the three structures $\mathbf{5} \mathbf{b}-\mathbf{A}, \mathbf{5} \mathbf{b}-\mathbf{B}$, and $\mathbf{5 b} \mathbf{b} \mathbf{C}$ and indicated that the enhydrazine $5 b-B$ is the most stable structure while $5 \mathrm{~b}-\mathrm{A}$ and $5 \mathrm{~b}-\mathrm{C}$ are less stable which agrees with the NMR spectral data. Although no significant activity of the first family of these compounds has been found as antibacterial, more derivatives are being prepared for overcoming the solubility problems, which are believed to be the cause of the poor biological activity.

\section{Additional Points}

Supporting Information. ${ }^{1} \mathrm{H}$ NMR, ${ }^{13} \mathrm{C}$ NMR spectra, and HRMS for the prepared compounds will be available online in Supplementary Material.

\section{Conflicts of Interest}

The authors declare no conflicts of interest.

\section{Acknowledgments}

The authors thank the International Scientific Partnership Program ISPP at King Saud University (ISPP\# 0061) (Saudi Arabia). The research at South Africa was funded by National Research Foundation (NRF) and the University of KwaZuluNatal.

\section{References}

[1] D. R. Shah, R. P. Modh, and K. H. Chikhalia, "Privileged s-triazines: structure and pharmacological applications," Future Medicinal Chemistry, vol. 6, no. 4, pp. 463-477, 2014.

[2] R. Kumar, A. D. Singh, J. Singh, H. Singh, R. K. Roy, and A. Chaudhary, "1,2,3-triazine scaffold as a potent biologically active moiety: a mini review," Mini-Reviews in Medicinal Chemistry, vol. 14, no. 1, pp. 72-83, 2014.

[3] J. P. Raval, A. R. Rai, N. H. Patel, H. V. Patel, and P. S. Patel, "Synthesis and in vitro antimicrobial activity of N'-(4-(arylamino)-6-(pyridin-2-ylamino)-1,3,5-triazin-2-yl)benzohydrazide," International Journal of ChemTech Research, vol. 3, no. 1, pp. 616-620, 2009.

[4] S. Nishigaki, F. Yoneda, H. Matsumoto, and K. Morinaga, "Synthetic antibacterials. I. Nitrofurylvinyl-s-triazine derivatives," Journal of Medicinal Chemistry, vol. 12, no. 1, pp. 39-42, 1969.

[5] D. H. Mahajan, C. Pannecouque, E. De Clercq, and K. H. Chikhalia, "Synthesis and studies of new 2-(coumarin-4-yloxy)4,6-(substituted)-S-triazine derivatives as potential anti-HIV agents," Archiv der Pharmazie, vol. 342, no. 5, pp. 281-290, 2009.
[6] Z. Nie, C. Perretta, P. Erickson et al., "Structure-based design, synthesis, and study of pyrazolo[1,5-a] $[1,3,5]$ triazine derivatives as potent inhibitors of protein kinase CK2," Bioorganic and Medicinal Chemistry Letters, vol. 17, no. 15, pp. 4191-4195, 2007.

[7] Z. Nie, C. Perretta, P. Erickson et al., "Structure-based design and synthesis of novel macrocyclic pyrazolo[1,5-a] [1,3,5]triazine compounds as potent inhibitors of protein kinase CK2 and their anticancer activities," Bioorganic and Medicinal Chemistry Letters, vol. 18, no. 2, pp. 619-623, 2008.

[8] V. K. Pandey, S. Tusi, Z. Tusi, M. Joshi, and S. Bajpai, "Synthesis and biological activity of substituted 2,4,6-s-triazines," Acta Pharmaceutica, vol. 54, no. 1, pp. 1-12, 2004.

[9] A. Agarwal, K. Srivastava, S. K. Puri, and P. M. S. Chauhan, "Synthesis of substituted indole derivatives as a new class of antimalarial agents," Bioorganic and Medicinal Chemistry Letters, vol. 15, no. 12, pp. 3133-3136, 2005.

[10] W. Zhu, Y. Liu, Y. Zhao et al., "Synthesis and biological evaluation of novel 6-hydrazinyl-2,4-bismorpholino pyrimidine and 1,3,5-triazine derivatives as potential antitumor agents," Archiv der Pharmazie, vol. 345, no. 10, pp. 812-821, 2012.

[11] V. R. Avupati, R. P. Yejella, V. R. Parala et al., "Synthesis, characterization and in vitro biological evaluation of some novel 1,3,5triazine-Schiff base conjugates as potential antimycobacterial agents," Bioorganic and Medicinal Chemistry Letters, vol. 23, no. 21, pp. 5968-5970, 2013.

[12] H. H. Al-Rasheed, M. Al Alshaikh, J. M. Khaled, N. S. Alharbi, and A. El-Faham, "Ultrasonic irradiation: synthesis, characterization, and preliminary antimicrobial activity of novel series of 4,6-disubstituted-1,3,5-triazine containing hydrazone derivatives," Journal of Chemistry, vol. 2016, Article ID 3464758, 9 pages, 2016.

[13] H. Singh, L. D. S. Yadav, K. N. Shukla, and R. Dwivedi, "Synthesis of new 1,3,4-oxadiazolo [3, 2-a]-s-triazine-5,7-dithiones and the dithionone analogues as potential antifungal agents," Indian Journal of Pharmaceutical Sciences, vol. 54, no. 1, pp. 33-37, 1992.

[14] M. Jarman, H. M. Coley, I. R. Judson et al., "Synthesis and cytotoxicity of potential tumor-inhibitory analogues of trimelamol (2,4,6-Tris[(hydroxymethyl)methylamino]-1,3,5-triazine) having electron-withdrawing groups in place of methyl," Journal of Medicinal Chemistry, vol. 36, no. 26, pp. 4195-4200, 1993.

[15] A. Dhainaut, G. Régnier, G. Atassi et al., "New triazine derivatives as potent modulators of multidrug resistance," Journal of Medicinal Chemistry, vol. 35, no. 13, pp. 2481-2496, 1992.

[16] D. C. Tahmassebi and T. Sasaki, "Synthesis of a three-helix bundle protein by reductive amination," Journal of Organic Chemistry, vol. 63, no. 3, pp. 728-731, 1998.

[17] J. Y. Lee, M. E. Brune, R. B. Warner et al., "Antihypertensive activity of ABBOTT-81282, a nonpeptide angiotensin II antagonist, in the renal hypertensive rat," Pharmacology, vol. 47, no. 3, pp. 176-187, 1993.

[18] L. Brunton, J. Lazo, and K. G. Parker, Gilman's The Pharmacological Basis of Therapeutics, Mc Graw-Hill, New York, NY, USA, 11th edition, 2005.

[19] M. W. Johns, "Sleep and hypnotic drugs," Drugs, vol. 9, no. 6, pp. 448-478, 1975.

[20] S. R. Whittle and A. J. Turner, "Differential effects of sedative and anticonvulsant barbiturates on specific [3H]GABA binding to membrane preparations from rat brain cortex," Biochemical Pharmacology, vol. 31, no. 18, pp. 2891-2895, 1982.

[21] H. Brunner, K.-P. Ittner, D. Lunz, S. Schmatloch, T. Schmidt, and M. Zabel, "Highly enriched mixtures of methohexital stereoisomers by palladium-catalyzed allylation and their anaesthetic 
activity," European Journal of Organic Chemistry, vol. 2003, no. 5, pp. 855-862, 2003.

[22] K. E. Lyons and R. Pahwa, "Pharmacotherapy of essential tremor: an overview of existing and upcoming agents," CNS Drugs, vol. 22, no. 12, pp. 1037-1045, 2008.

[23] C. Uhlmann and W. Fröscher, "Low risk of development of substance dependence for barbiturates and clobazam prescribed as antiepileptic drugs: results from a questionnaire study," CNS Neuroscience and Therapeutics, vol. 15, no. 1, pp. 24-31, 2009.

[24] E. Maquoi, N. E. Sounni, L. Devy et al., "Anti-invasive, antitumoral, and antiangiogenic efficacy of a pyrimidine-2,4,6-trione derivative, an orally active and selective matrix metalloproteinases inhibitor," Clinical Cancer Research, vol. 10, no. 12 I, pp. 4038-4047, 2004.

[25] H.-J. Breyholz, S. Wagner, A. Faust et al., "Radiofluorinated pyrimidine-2,4,6-triones as molecular probes for noninvasive MMP-targeted imaging," ChemMedChem, vol. 5, no. 5, pp. 777789, 2010.

[26] P. Bartsch, D. Cataldo, R. Endele et al., "Pharmaceutical compositions of pyrimidine-2, 4, 6-triones," Google Patents, 2011.

[27] J. A. Richter and J. R. Holtman Jr., "Barbiturates: their in vivo effects and potential biochemical mechanisms," Progress in Neurobiology, vol. 18, no. 4, pp. 275-319, 1982.

[28] A. Padmaja, G. S. Reddy, A. Venkata Nagendra Mohan, and V. Padmavathi, "Michael adducts-Source for biologically potent heterocycles," Chemical and Pharmaceutical Bulletin, vol. 56, no. 5, pp. 647-653, 2008.

[29] V. Padmavathi, G. D. Reddy, B. C. Venkatesh, and A. Padmaja, "One-pot synthesis of 5-[Bis(azolylmethylthio)]methylenepyrimidine-2,4,6- (1H,3H,5H)-triones," Archiv der Pharmazie, vol. 344, no. 3, pp. 165-169, 2011.

[30] D. M. Neumann, A. Cammarata, G. Backes, G. E. Palmer, and B. S. Jursic, "Synthesis and antifungal activity of substituted 2,4,6-pyrimidinetrione carbaldehyde hydrazones," Bioorganic \& Medicinal Chemistry, vol. 22, no. 2, pp. 813-826, 2014.

[31] H. A. Ghabbour and A. El-Faham, "Crystal structure of 4-chloro-N,N-diethyl-6-(piperidin-1-yl)-1,3,5-triazin-2-amine, C12H20ClN5," Zeitschrift fur Kristallographie-New Crystal Structures, vol. 231, no. 1, pp. 243-245, 2016.

[32] S. T. Asundaria, S. A. Patel, K. M. Mehta, and K. C. Patel, "Synthesis, characterization and antimicrobial studies of some novel 1,3,4-thiadiazolium-2-thiolate derivatives," South African Journal of Chemistry, vol. 63, pp. 141-144, 2010.

[33] B. S. Jursic and D. M. Neumann, "Preparation of 5-formyland 5-acetylbarbituric acids, including the corresponding Schiff bases and phenylhydrazones," Tetrahedron Letters, vol. 42, no. 48, pp. 8435-8439, 2001.

[34] T. J. Mooibroek and P. Gamez, "The s-triazine ring, a remarkable unit to generate supramolecular interactions," Inorganica Chimica Acta, vol. 360, no. 1, pp. 381-404, 2007.

[35] A. Solankee and R. Tailor, "Synthesis, characterisation and biological screening of s-triazine based chalcones and its derivatization into phenyl pyrazolines, isoxazoles," International Letters of Chemistry, Physics and Astronomy, vol. 47, pp. 109-119, 2015.

[36] S. D. Desai, K. R. Desai, K. H. Chikhalia, C. Pannecouque, and E. De Clercq, "Synthesis of a novel class of some 1, 3, 5-triazine derivatives and their anti-HIV activity," International Journal of Drug Design and Discovery, vol. 2, pp. 361-368, 2011.

[37] B. Liu, T. Sun, Z. Zhou, and L. Du, "A systematic review on antitumor agents with 1, 3, 5-triazines," Medicinal Chemistry, vol. 5, pp. 131-148, 2015.
[38] A. Sharma, Y. Jad, H. Ghabbour et al., "Synthesis, crystal structure and DFT studies of 1,3-Dimethyl-5-propionylpyrimidine2,4,6(1H,3H,5H)-trione," Crystals, vol. 7, no. 1, p. 31, 2017.

[39] E. Giziroglu, M. Aygün, C. Sarikurkcu et al., "Synthesis, characterization and antioxidant activity of new dibasic tridentate ligands: X-ray crystal structures of DMSO adducts of 1,3dimethyl-5-acetyl-barbituric acid o-hydroxybenzoyl hydrazone copper(II) complex," Inorganic Chemistry Communications, vol. 36, pp. 199-205, 2013. 

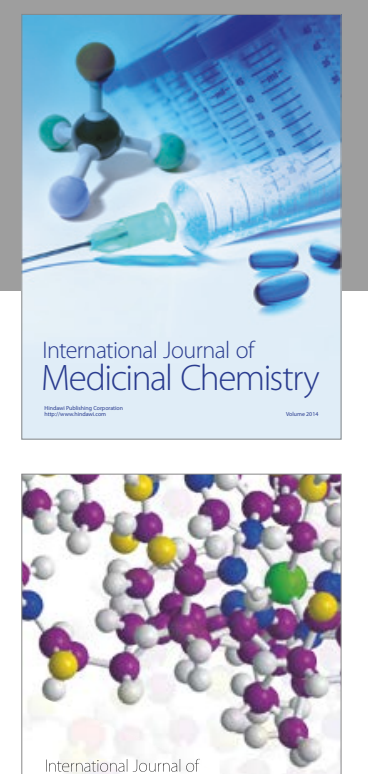

Carbohydrate Chemistry

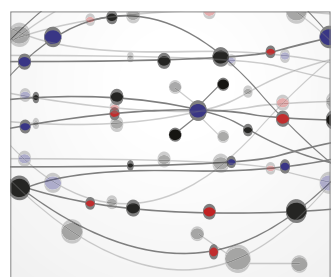

The Scientific World Journal
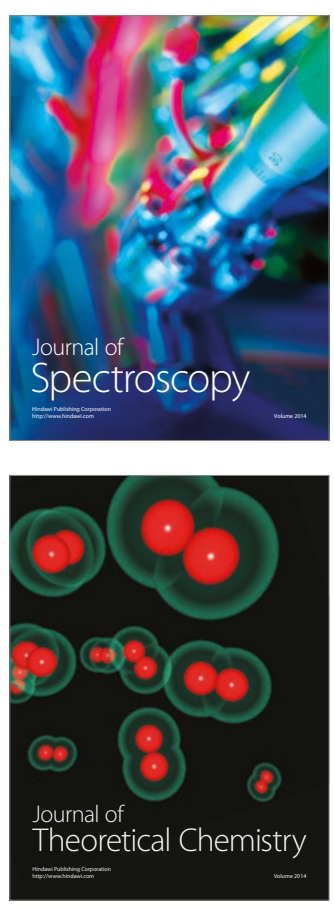
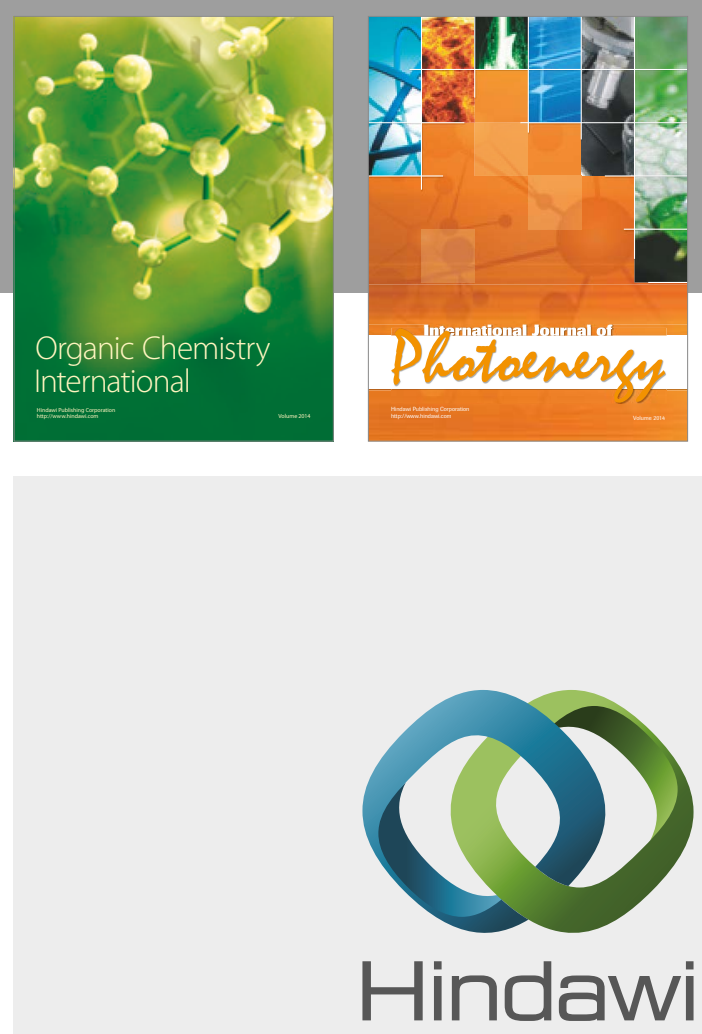

Submit your manuscripts at

https://www.hindawi.com

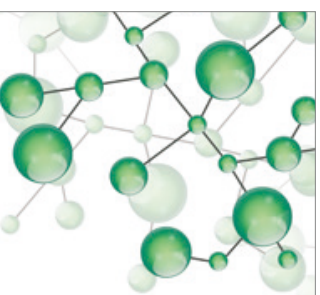

International Journal of

Inorganic Chemistry

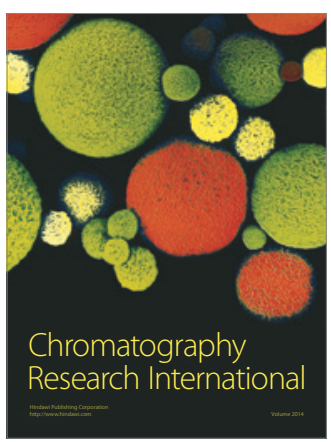

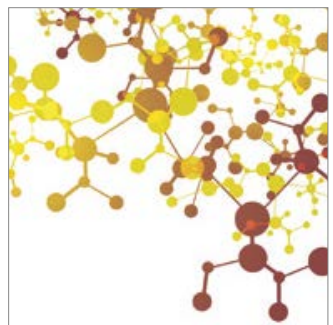

Applied Chemistry
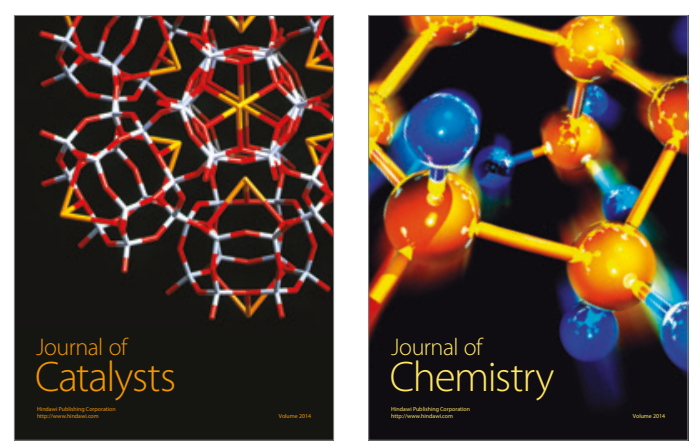
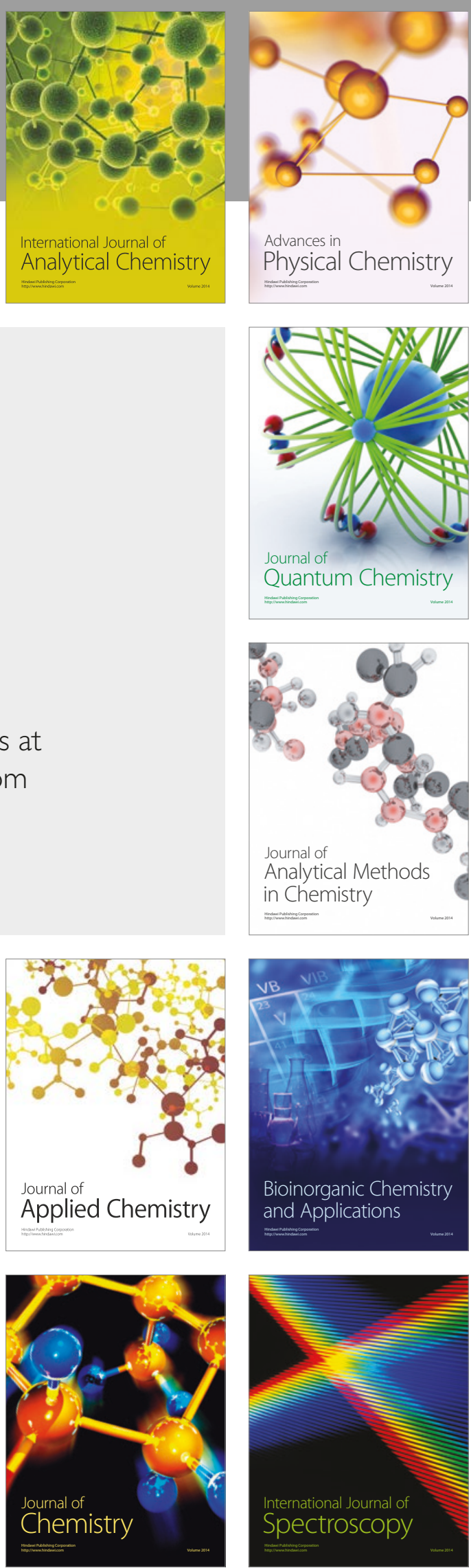